\title{
The politics of health-care reform in the Netherlands since 2006
}

Citation for published version (APA):

Maarse, J. A. M., \& Paulus, A. T. G. (2011). The politics of health-care reform in the Netherlands since 2006. Health Economics, Policy and Law, 6(1), 125-134. https://doi.org/10.1017/S174413311000037X

Document status and date:

Published: 26/01/2011

DOI:

10.1017/S174413311000037X

Document Version:

Publisher's PDF, also known as Version of record

\section{Please check the document version of this publication:}

- A submitted manuscript is the version of the article upon submission and before peer-review. There can be important differences between the submitted version and the official published version of record.

People interested in the research are advised to contact the author for the final version of the publication, or visit the DOI to the publisher's website.

- The final author version and the galley proof are versions of the publication after peer review.

- The final published version features the final layout of the paper including the volume, issue and page numbers.

Link to publication

\footnotetext{
General rights rights.

- You may freely distribute the URL identifying the publication in the public portal. please follow below link for the End User Agreement:

www.umlib.nl/taverne-license

Take down policy

If you believe that this document breaches copyright please contact us at:

repository@maastrichtuniversity.nl

providing details and we will investigate your claim.
}

Copyright and moral rights for the publications made accessible in the public portal are retained by the authors and/or other copyright owners and it is a condition of accessing publications that users recognise and abide by the legal requirements associated with these

- Users may download and print one copy of any publication from the public portal for the purpose of private study or research.

- You may not further distribute the material or use it for any profit-making activity or commercial gain

If the publication is distributed under the terms of Article $25 \mathrm{fa}$ of the Dutch Copyright Act, indicated by the "Taverne" license above, 


\title{
Debate
}

\section{The politics of health-care reform in the Netherlands since 2006}

\author{
HANS MAARSE* AND AGGIE PAULUS
}

Faculty of Health, Medicine and Life Sciences, Department of Health Organisation, Policy and Economics, University of Maastricht, The Netherlands

\begin{abstract}
This article comments on Schut and van de Ven's overview of the results of purchaser competition in Dutch health care, which concludes that the glass can be seen as half full or half empty. Although it is true that results have been achieved, we believe that the evidence is incomplete and in some respects flimsy. More importantly, however, Schut and van de Ven neglect the political context of the market reform introduced in 2006. The reform is far from finished and there has been a constant need for political compromise. Optimism about the market's potential also seems to be on the wane. Several insurer and provider initiatives have provoked political resistance. As a result, there are good reasons to argue that the reform's future is uncertain.
\end{abstract}

\section{Introduction}

Dutch health-care reform, in particular health insurance reform, has attracted wide international attention. Yet it is important to note that the integration of the former sickness fund scheme and private health insurance arrangements into a single mandatory national scheme with competition between insurers and freedom of choice for consumers (van de Ven and Schut, 2008) is only the first step in the reform process. One may even argue that the new health insurance scheme does not make up the essence of the reform. The real test is whether the reform makes health-care delivery more efficient, innovative and patientoriented without compromising the so-called public interests of solidarity, universal access, affordability and quality of care. Health insurance reform plays only an instrumental role in this respect - a point that tends to be overlooked by international observers. Competition in health insurance does not make much sense, if it is not accompanied by competition in purchasing and health-care delivery.

\footnotetext{
*Correspondence to: Hans Maarse, Faculty of Health, Medicine and Life Sciences, Department of Health Organisation, Policy and Economics, University of Maastricht, PO Box 616, 6200 MD Maastricht, The Netherlands. Email: h.maarse@maastrichtuniversity.nl
} 
Schut and van de Ven (2011) address an important issue in their overview of the effects so far of purchaser competition. They take as their leading question 'whether and how insurers are taking up their role as purchasers of health services'. This question relates to a fundamental assumption underpinning the Dutch reform - namely, that health insurers will play a key role in the restructuring of health care. Spurred by competition, they will act as prudent purchasers. In doing so - the theory goes - health-care providers will be forced to perform better in terms of efficiency, innovation, quality of care and patientorientation. High-performing providers will be rewarded with contracts, while poor performers may lose contracts.

What can we conclude from Schut and van de Ven's concise but interesting overview of the evidence of purchaser competition? Is the glass half full or half empty? They do not give a definitive answer to this question. Instead, they argue that the answer depends on one's perspective: given the evidence available, the glass may be seen as half full (the optimist's view) or as half empty (the pessimist's view).

Our comments address three topics. First, we briefly analyse the institutional and market context of purchaser competition. This analysis is followed by a short reconsideration of the evidence presented by Schut and van de Ven. Although it is true that results have been achieved, we believe that the evidence is incomplete and in some respects flimsy. Second, Schut and van de Ven neglect the politics of health-care reform after 2006. Building a political majority for the new health insurance act in 2005 was quite a performance, but the road to further reform is paved with political obstacles. In fact, the government still needs to take several market-making decisions, which means the eventual shape of the reform is uncertain. For our third topic, we briefly discuss a few cases of what is termed the real world of the market reform to illustrate its still controversial nature. To conclude, we find that there is more reason to be pessimistic than optimistic about the impact of the market reform.

\section{Reconsidering the evidence}

Schut and van de Ven give a helpful overview of what purchaser competition has achieved so far - no easy task due to the lack of good evidence. The available evidence is patchy, to a large extent based on qualitative data and, in most respects, more anecdotal than systematic. However, the general impression is that insurers have mainly focused on prices and much less on the quality of care. There are several explanations for this.

First, for a long period there were hardly any systematic, comparable data on the quality of hospital services. The situation has improved somewhat, but to take a big leap forward requires much more information on quality, as Schut and van de Ven rightly point out. Second, in 2006 neither insurers nor hospitals had much experience of negotiating on price or quality. The third factor is 
market structure. The room for purchaser competition is quite different in a market with many competitors from a market with only one provider. Extensive collective bargaining is still the norm in the Netherlands. For example, for services in the price-regulated segment of hospital care (segment A), the leading insurer in a region determines contracts with a hospital and the other insurers simply conform to this contract. An implication of this collective model is that the market leader cannot negotiate any exclusive advantage - so an agreement on waiting times applies to all other insurers. Hospitals adhere to the principle of equal treatment and are reluctant to give an insurer an exclusive contract based on quality for fear it may damage their reputation. Finally, purchaser competition assumes patient steering, but this is controversial for many patients, whose prevailing perception is that insurers are driven more by money than quality. Insurers therefore have a credibility problem (Boonen, 2009), an important reason why they have largely abstained from selective contracting so far. Once again, they fear reputation damage.

Schut and van de Ven present some data to substantiate their claims, paying attention to the effects of purchaser competition on hospital prices. The data indicate that price increases in the free-pricing segment of hospital care (segment B) are lower than in segment A (see their Table 3). However, there are reasons to be careful in drawing firm conclusions here. The method used to calculate price increases in segment A differs from the method used in segment B. Calculations are based on factor prices in the former and on $\mathrm{DTC}^{1}$ prices in the latter. Another problem is comparability. To what extent are the medical services in segment $B$ comparable to the medical services in segment A? New, often very expensive, medical interventions are likely to concentrate in segment A. And one may wonder to what extent price increases in segment $B$ really match the market advocates' expectations. Are they satisfied with the results?

A further issue is volume. Do hospitals offset lower prices in segment B by an increase in the number of services? Schut and van de Ven present a single figure to argue that a volume increase did not incur in segment $\mathrm{B}$. We believe this evidence is too flimsy to substantiate their claim. Moreover, the claim is counterintuitive, since Schut and van de Ven also argue that waiting times have fallen. As there is no reason to assume a decline in demand for care, shorter waiting times can only have been achieved by an increase in volume.

In addition, we do not know whether the volume of services produced by the so-called independent treatment centres (ITCs) is included in the analysis. ITCs are small-scale specialised organisations mainly providing high-volume routine care to patients in fields such as ophthalmology, dermatology, maternity care, orthopaedic surgery, cosmetic surgery, radiology and cardiology. The number of

1 Diagnosis Treatment Combinations (DTCs) are used for case mix-based funding of hospitals and are comparable to diagnosis-related groups. DTCs exist for inpatient and outpatient hospital care (see Maarse and Normand, 2009 for further details). 
Table 1. Cost increase per insured 2003-2008 (€)

\begin{tabular}{lrrrrrr}
\hline \hline & $2003 *$ & $2004 *$ & $2005 *$ & $2006 * *$ & $2007 * *$ & $2008 * *$ \\
\hline General Practitioner care & 103 & 102 & 102 & 119 & 124 & 127 \\
Physiotherapy & 48 & 20 & 22 & 21 & 24 & 27 \\
\hline \hline
\end{tabular}

*Only sickness fund insured.

**All insured.

Source: CVZ (2009).

ITCs has risen substantially from 30 in 2000 to about 180 in 2009 (Maarse and Normand, 2009). There are indications that the cost overruns in 2009 were partly due to a sharp increase in the volume of health services produced by ITCs (Financieel Dagblad, 14 April 2010).

There are other indications of a volume effect, which Schut and van de Ven do not discuss. For example, the data in Table 1 demonstrate a dramatic increase in the general practitioner (GP) care costs per insured since 2006. It is likely that this increase is to a great extent caused by the new fee-for-service elements in the GP payment system introduced in 2006. Whereas the number of patient consultations per GP practice per year in 2006 was assumed to be 8296, it turned to be 9439 (CVZ, 2009). There is no evidence that the cost increases in GP care were offset by a decrease in the costs of hospital care per insured (the so-called substitution effect). In physiotherapy the sharp decline seen in 2004 was the result of a substantial cut in the amount of physiotherapy included in the benefits package of the sickness fund scheme. From 2005 physiotherapy prices have been open to negotiation. Since then, the costs per insured have risen steadily, but because the price of physiotherapy services stabilised after 2006, the cost increase may be attributed to a volume effect (CVZ, 2009).

Another reason for some scepticism about the effects of the market reform concerns the increase in premiums for both basic (statutory) and complementary (voluntary) health insurance. The community-rated premium for basic coverage (corrected for the shift from a no-claims bonus to a mandatory deductible in $2008)^{2}$ grew by $8.8 \%$ in 2007 and by $5.2 \%$ in 2008 (Vektis, 2009). The incomerelated contribution rate increased from $6.5 \%$ of income in 2006 and 2007 to $7.2 \%$ in 2008. Premiums for complementary coverage grew by $8.6 \%$ in 2007 and $8.3 \%$ in 2008 . In our view, this premium growth does not point to great success - and bear in mind that insurers made a loss on basic health insurance (see Schut and van de Ven (2011) for further details).

2 The new health insurance scheme originally included a no-claims bonus - in essence a pre-paid copayment of $€ 255$ in addition to the community-rated health insurance premium. The money was refunded to the subscriber in proportion to the costs of their medical consumption (excluding GP care, maternity care and care for children aged under 18). The arrangement was abolished in 2008 due to its very limited effect on medical consumption, and replaced with a mandatory deductible of $€ 155$. 
In summary, in considering whether the glass is half full or half empty, we tend to think it is more empty than filled. In the following sections, we will substantiate our view further by analysing the politics of the market reform from 2006 onwards.

\section{The politics of market making}

Implementation of the market reform in health insurance fundamentally differs from implementation of the market reform in purchasing and health-care delivery. For health insurance, the government followed a 'big bang' strategy. When the new health insurance legislation came into force the sickness fund scheme and all substitutive private health insurance plans ceased to exist and were replaced with the new scheme. The only precautionary measure to avoid market disruption was the adoption of a safety net that put a limit on an insurer's maximum gain or loss per subscriber. Intended to be a temporary measure to ease the transition, the net - part of the ex-post risk equalisation scheme - is still in place today, although the government has said it will phase it out from 2011.

In contrast, in implementing market reform of purchasing and health-care delivery the government has pursued a step-wise strategy. For example, in 2005 segment B hospital procedures accounted for only $10 \%$ of total hospital expenditure (in reality it was even less), rising to about $20 \%$ in 2008 and about $34 \%$ in 2009 . A political decision about a further increase to $50 \%$ is pending. The incremental approach has been adopted in other areas such as pharmacy, midwife and orthodontic care. The government's central planning regime for hospital care was only abolished in 2008 (2009 for long-term care).

The main reason for this 'cautious implementation strategy' (as the government terms it) lies in three interconnected factors: uncertainty, risk avoidance and political controversy. Uncertainty relates to the outcomes of the market reform. What will the consequences of competition be? Positively formulated, one may speak here of the adoption of a learning model. There must be empirical evidence to show that the market works as expected by its advocates and that there are no adverse effects on the quality and accessibility of health care. For this reason, the effects of the market reform are constantly monitored and evaluated by the Netherlands Healthcare Authority (NZa), an arm's length agency in charge of market regulation and development.

Risk avoidance means avoiding disruption in health-care delivery at any price. Health care is politically and socially too sensitive an area for risky policy experiments and therefore requires an incremental implementation strategy. Only if competition works can further steps be taken; if it does not work or adverse effects occur, remedial policy measures will be necessary. However, policy learning and risk avoidance cannot be seen as isolated from the politically controversial nature of the market reform. Caution and incremental decision-making 
also arise due to the constant need to find a political compromise between market advocates and opponents. For example, in the policy programme of the government that took office in 2007, the coalition parties agreed that further steps towards freely negotiable prices in hospital care could only be taken after a careful evaluation (by the $\mathrm{NZa}$ ) of the effects of previous steps on the quality and accessibility of care.

Two other controversial policy issues illustrate how far the market reform is from being finished. The first issue can be framed in terms of the tension between freedom (market) and the need for control. On one hand, the government sees competition as an effective instrument to foster efficiency. In the market model, total health-care expenditures are the 'spontaneous' product of volume and prices. On the other hand, however, total health-care expenditures should not exceed predetermined budget ceilings set by the government. In other words, market competition must be combined with total (or macro) budget control and the government needs an instrument to offset any overruns by skimming provider revenues.

It is clear that this strategy of market competition with budget control forms a political compromise between those who favour market competition and those who are concerned about uncontrollable health-care expenditures (such as the Ministry of Finance). In fact, the government's policy proposal looks like squaring the circle, as the Netherlands Hospital Association immediately noted. The NZa acknowledged the need for effective cost control, but argued that other and better instruments were available to keep expenditures within predetermined budget limits such as benchmarking, raising the mandatory deductible or reducing the benefits package of the new health insurance scheme. The Minister of Health considered the last two instruments 'the easy way' and, for that reason, politically unattractive. The new government will have to resolve this issue and its decision will certainly be influenced by the political composition of the coalition.

This is also the case for another political issue. Traditionally, there has been a ban on for-profit hospital care in the Netherlands. Hospitals must function as non-profit entities. They are permitted to retain a budget surplus (just as they are responsible for budget deficits), but are obliged to reinvest the surplus in providing care. When the market reform began, the government saw the lifting of the ban as a 'natural' element of it. However, lifting the ban was not seen as a priority and was postponed. The Netherlands Hospital Association is strongly in favour of lifting the ban, the more so because hospitals are responsible for financing capital investment (included in the price of each DTC) and increasingly rely on external private investors (Maarse and Normand, 2009). Private investors will only be interested if they can expect a return on investment and, as (co-) owner, can influence strategic decision-making.

Since for-profit hospital care is still controversial, the government has had to compromise. It has emphasised not wanting a commercial type of hospital. 
Private investors can be paid 'a result-related compensation for risk capital', but they do not have the status of co-owner and are not permitted to have a dominant influence on the hospital's management either. They are only given the right to appoint a single member of the hospital's supervisory board. Nor can they sell their profit certificate without the supervisory board's approval. It does not come as a surprise that this proposal was heavily criticised by the hospital association and private investors. The comment of the latter was short: the compromise will not work. The CEO of a big pension fund (seen as an important potential investor) stated that pension funds could not be expected to function as the health system's 'cash dispenser'. How the issue will be settled remains unclear.

The list of examples could easily be extended. The message, however, is clear. The market reforms are far from finished, decisions need to be taken and decision-making is surrounded by political controversy. A significant development is that the Labour Party has expressed doubts as to whether the market reform should be continued (Bos, 2010). The Vice-President of the Highest Advisory Council has also recently criticised the 'market state' (Raad van State, 2010). As a result of these issues, the future shape of the market reform is uncertain - nobody really knows how it will eventually look. A cautious approach to avoid disruption has its advantages, but also comes at a price: the risk of half-way implementation due to results lagging behind expectations, unexpected difficulties, increasing costs, a changing political environment and so on. Of course, advocates of the market reform hold a different view. They argue that a fault confessed is half redressed.

\section{Market reform in the real world}

Our discussion of the market reform has so far concentrated on political decision-making at government level. In this section we turn our attention to politics at the local level. We briefly discuss three cases, each of which attracted significant political attention at the national level, including the involvement of the Minister of Health. The cases shed light on the real world of the market reform.

The first case concerns the IJsselmeer Ziekenhuizen (IJsselmeer Hospitals). In 2008, the IJZ was close to bankruptcy. It had lost a lot of market share to neighbouring hospitals. The quality of its care did not meet all standards and the hospital had been paralysed by many years of internal conflicts following a merger in the early 1990s. Market advocates always stipulate that, as a matter of fact, competition will inevitably result in provider bankruptcies. But did the IJZ go bankrupt? After a period of intensive consultation and negotiation the $\mathrm{NZa}$ eventually decided to give the hospital financial support. A private entrepreneur, now the chairman of the hospital's executive board, also invested in the hospital. The Minister of Health was heavily involved in the decision-making process. He took the position that he did not feel responsible for the continuity of an individual hospital, but could only be held accountable for the continuity 
of hospital care in the region where a hospital in financial trouble was located. Following the report of an external advisor (Lodewick, 2008), he concluded that continuity and accessibility were seriously at risk in this case, declaring the hospital to be 'a system hospital' vital to the region.

The IJZ case contains several lessons. Creative destruction through bankruptcy appears to be uncommon where hospitals are concerned. The criterion of continuity is more abstract than concrete, leaving decision-makers with considerable policy discretion. Decision-making takes place in a complex political-administrative environment involving a myriad of actors with mutual dependencies. Insurers also face a quandary. Following the logic of selective contracting, they would have had good reason not to contract the IJZ or only in a selective way due to its non-competitive prices and the failing quality of some of its hospital services. But selective contracting would have influenced regional accessibility to hospital care and would certainly have caused negative publicity. Furthermore, the new health insurance act obliges insurers to purchase care of sufficiently high quality for their subscribers. So insurers continued to contract the hospital and the ex-post risk equalisation arrangement enable them to shift the extra costs to the equalisation fund. A further issue was whether financial support to the hospital was in accordance with European Union competition law, which only allows for state support under strict conditions (RVZ, 2009).

IJZ is not an isolated case. In the last few years, there have been several bankruptcies, particularly in home care, but most of them concerned small organisations whose services and personnel could easily be taken over by others. One large home care provider (Meavita) also went bankrupt due to serious mismanagement. Again, the Minister of Health was heavily involved, again closely orchestrating financial support. At present various hospitals are financially at risk or even technically bankrupt. It remains to be seen what will happen with these hospitals and how the Minister of Health will respond.

The second case also concerns a hospital in financial trouble. In 2009, local actors decided to invest in and take over the Vlietland Hospital (VH) to tackle its problems. Among the actors in the consortium were medical specialists, general practitioners, long-term care providers and the dominant regional insurer, which would acquire $40 \%$ of the consortium's shares. The insurer's substantial stake made the takeover resemble a form of vertical integration, which had been forbidden prior to the 2006 reform, but is now permitted. Since the ban on vertical integration was lifted several insurers have become involved in financing provider organisations. However, this particular instance was heavily resisted in parliament and the Minister of Health was asked to forbid the integration on the grounds that it would severely restrict freedom of choice one of the objectives of the reform - for the insurer's subscribers. Every party in the consortium would have a financial interest in referring patients to the VH.

Vlietland's experience reveals several things. First, it shows how the reform objective of choice for subscribers seemed to conflict with another strategic 
goal - that insurers and providers should be responsible for addressing their own problems and ensuring access to health care. Second, it shows how controversial the reform is: even politicians who support it do not always accept its consequences. Third, it raises the question of whether the consortium would have genuinely restricted the choice of the local population. Not only is the hospital in an area with several other hospitals nearby (Baarsma et al., 2009), but if it had gone bankrupt this would have given patients one option less. Finally, it is worth noting that the local population was in fact very interested in keeping its own hospital open.

The third case concerns an initiative of the Kennemer Gasthuis (KG) to enhance patients' freedom. KG gave its patients the option of being treated faster for extra payment, legitimising its initiative by stating that the extra revenues would be reinvested in hospital care so that eventually everybody would benefit from the arrangement (the so-called Robin Hood model). However, media reports led to a social and political outcry. The hospital's initiative was perceived as a violation of the principle of equal access and, as in the previous case, the Minister of Health was asked to put an end to the experiment. It eventually turned out that the initiative was not in accordance with healthcare legislation, but in the first instance it was disqualified as an example of twotier care and queue jumping, reflecting the prevailing egalitarian culture in Dutch health care.

KG's case is not an isolated one (Putters, 2001). Several providers now offer their clients extras for additional payment. Single hospital rooms, which have largely disappeared over the last three decades, are emerging once more. As market competition leads to a more differentiated supply system, which may conflict with the principle of equal access, it has ignited a debate about whether it is possible and legitimate to draw a line between basic health services (where the principle of universal and equal access applies) and additional health services.

\section{Conclusion}

Schut and van de Ven present an interesting overview of the results of purchaser competition in Dutch health care. They conclude that it depends on one's perspective whether one considers the glass to be half full or half empty. We believe they are too optimistic and neglect the political context of the market reform, which is far from complete and requires constant political compromise. Optimism about the market's potential seems to be on the wane and there are good reasons to argue that the reform's future is uncertain. Schut and van de Ven argue that 'the effectiveness of purchaser competition crucially depends on the success of the ongoing efforts to improve performance indicators, product classification and the system of risk equalisation'. While these are important policy issues, they suggest that further development of the market reform is primarily a technical issue, a kind of intellectual puzzle. We have argued that this view is fundamentally flawed. 


\section{References}

Baarsma, B., E. van Damme, Th. van Dijk, T. Ottervanger and W. Verloren van Themaat (2009), 'Eindrapport commissie verticale integratie tussen zorgverzekeraars en zorgaanbieders' (report).

Boonen, L. (2009), 'Consumer channeling in health care: (im)possible?', PhD thesis, Erasmus University, Rotterdam.

Bos, W. (2010), 'De derde weg voorbij'. DenUyl Lecture. Amsterdam.

CVZ (College voor Zorgverzekeringen) (2009), Zorgciffers Kwartaalbericht: 1e kwartaal 2009, Amstelveen (report).

Lodewick, L. (2008), Ziekenhuiszorg in de polders. Een herontwerp, Maastricht (report).

Maarse, H. and C. H. Normand (2009), 'Market Competition in European Hospital Care', in B. Rechel, S. Wright, N. Edwards, B. Dowesdill and M. McKee (eds), Investing in Hospitals of the Future, Denmark: WHO, 103-122.

Putters, K. (2001), 'Geboeid ondernemen', PhD thesis, Erasmus University, Rotterdam.

Raad van State (2010), Jaarverslag 2009, Den Haag (report).

RVZ (Raad voor de Volksgezondheid en Zorg) (2009), 'Steunverlening zorginstellingen' (report). Zoetermeer.

Schut, F. and W. van de Ven (2011), 'Effects of purchaser competition in the Dutch health care system: is the glass half full or half empty?', Health Economics, Policy and Law, 6(1): 109-123.

van de Ven, W. and F. Schut (2008), 'Universal mandatory health insurance in the Netherlands', Health Affairs, 3: 371-381.

Vektis (2009), Jaarcijfers 2009, Zeist. 